\title{
Penerapan Pembelajaran Tatap Muka Terbatas di Masa Pandemi Covid-19 pada Lembaga PAUD
}

\author{
Ismatul Izza Al Iftitah ${ }^{1 凶}$, Amir Syamsudin ${ }^{1}$ \\ Pendidikan Anak Usia Dini, Universitas Negeri Yogyakarta, Indonesia( ${ }^{(1)}$ \\ DOI: $\underline{10.31004 / o b s e s i . v 6 i 3.2079}$
}

\begin{abstract}
Abstrak
Artikel ini bertujuan untuk mengetahui penerapan pembelajaran tatap muka terbatas di lembaga PAUD selama masa pandemi covid-19. Keputusan untuk membuka sekolah-sekolah di Indonesia tertuang berdasarkan Surat Keputusan Bersama (SKB) 4 Menteri, yaitu Menteri Pendidikan dan Kebudayaan, Menteri Agama, Menteri Kesehatan, dan Menteri Dalam Negeri, Nomor 737 Tahun 2020. Penelitian ini merupakan penelitian kualitatif deskriptif menggunakan teknik pengumpulan data studi pustaka atau literatur. Penelusuran artikel diambil dari berbagai sumber sekunder antara lain buku, jurnal, serta dokumendokumen terkait penelitian. Hasil penelitian menunjukkan penerapan pembelajaran tatap muka terbatas di lembaga PAUD membutuhkan persiapan seperti sarana protokol kesehatan, surat persetujuan orang tua, dan pelaksanaannya wajib mematuhi prinsip $5 \mathrm{M}$, mengatur jadwal keberangkatan anak ke sekolah, mengurangi waktu belajar, dan kegiatan yang dilakukan anak cukup dengan 1 kegiatan. Penelitian ini memberikan interpretasi baru mengenai pembelajaran tatap muka terbatas pada lembaga PAUD yang telah diteliti pada penelitian-penelitian sebelumnya.
\end{abstract}

Kata Kunci: Pembelajaran tatap muka terbatas; PAUD; pandemi covid-19.

\begin{abstract}
This article aims to find out the application of limited face-to-face learning in PAUD institutions during the covid-19 pandemic. The decision to open schools in Indonesia is based on a Joint Decree (SKB) of 4 Ministers, namely the Minister of Education and Culture, the Minister of Religion, the Minister of Health, and the Minister of Home Affairs, Number 737 of 2020. This research is a descriptive qualitative study using data collection techniques. literature study data or literature. Article searches were taken from various secondary sources including books, journals, and documents related to research. The results showed that the application of limited face-to-face learning in early childhood education institutions required preparations such as health protokol facilities, parental approval letters, and the implementation was required to comply with the 5M principle, set the schedule for the child's departure to school, reduce study time, and activities carried out by children only with 1 activity.
\end{abstract}

Keywords: Limited face-to-face learning; early childhood education ; covid-19 pandemic.

Copyright (c) 2022 Ismatul Izza Al Iftitah, Amir Syamsudin.

$\triangle$ Corresponding author :

Email Address : ismatulizza.2020@student.uny.ac.id (Lampung, Indonesia)

Received 15 October 2021, Accepted 6 January 2021, Published 16 January 2022 


\section{PENDAHULUAN}

Munculnya pandemi covid-19 di Indonesia pada awal Januari tahun 2020 tidak hanya mempengaruhi kondisi kesehatan masyarakat Indonesia, tetapi juga perekonomian, pendidikan, dan kehidupan social masyarakat (Isdijoso et al., 2020). Ketiga sektor ini banyak mengalami perubahan yang signifikan dan sangat dapat dirasakan efeknya pada masyarakat. Pengaruh pandemi covid-19 terhadap sektor pendidikan terjadi pada seluruh tingkat pendidikan, mulai dari PAUD hingga perguruan tinggi. Dampak yang paling dirasa yaitu penutupan sekolah-sekolah demi memutuskan rantai penyebaran virus covid-19, digantikan dengan pembelajaran jarak jauh menggunakan teknologi digital (Syah, 2020) tak terkecuali pada tingkat pendidikan paling rendah, yaitu pendidikan anak usia dini.

Pembelajaran jarak jauh ini mulai diberlakukan sejak dikeluarkannya (Surat Keputusan Nomor 4 Tahun 2020 tentang Pelaksanaan Kebijakan Pendidikan dalam Masa Darurat Penyebaran Corona Virus Disease (Covid-19), 2020) pada tanggal 24 Maret 2020. Metode yang digunakan dalam pembelajaran jarak jauh di PAUD sangat bervariasi, seperti penggunaan whatsapp group, penayangan melalui TVRI, pemberian tugas, penggunaan aplikasi yang dapat menghubungkan video konferens, penggunaan platform social media, proyek, kolaboratif, blended learning, serta permainan (Satrianingrum et al., 2021). Meskipun pembelajaran jarak jauh telah diusahakan berjalan dengan maksimal, menurut penelitian yang dilakukan Satriana et al. (2021) selama 8 bulan yakni dari Agustus 2020-Maret 2021, pembelajaran jarak jauh tidak efektif untuk diterapkan pada anak usia dini karena jaringan internet yang kurang stabil, anak kurang fokus menyimak guru, dan kurangnya ketertarikan anak pada pembelajaran online. Senada dengan pendapat sebelumnya, disebutkan kembali oleh Supono \& Tambunan (2021) pembelajaran daring tidak dapat berjalan secara maksimal karena beberapa hal. Oleh karena itu hal ini menjadi tantangan baru bagi guru dan orang tua dalam pelaksanaan pembelajaran jarak jauh bagi anak usia dini.

Seiring berjalannya waktu, pembelajaran jarak jauh yang dirasa kurang maksimal membuat pemerintah mengeluarkan keputusan untuk membuka sekolah-sekolah di Indonesia. Hal ini tertuang berdasarkan Surat Keputusan Bersama (SKB) 4 Menteri, yaitu Menteri Pendidikan dan Kebudayaan, Menteri Agama, Menteri Kesehatan, dan Menteri Dalam Negeri, Nomor 737 Tahun 2020, tentang pembelajaran tatap muka namun belum wajib. Kemudian ditunjang panduan penyelenggaraan pembelajaran pauddikdasmen di masa pandemi covid-19 yang dikeluarkan (Kemendikbud \& Kementerian Agama, 2021). Dibukanya sekolah-sekolah ini disambut baik oleh para orang tua (Sholikhah, 2021). Lebih dalam pernyataan serupa didorong oleh pendapat Supriyanto \& Rozaq (2021) bahwa pembelajaran tatap muka sangat penting, pembelajaran terbaik ialah tatap muka, profesi guru tidak dapat digantikan dengan teknologi. Dengan demikian penulis setuju mengenai dibukanya sekolahsekolah di Indonesia, khususnya PAUD. Meskipun pembelajaran masih dilakukan secara terbatas, setidaknya pembelajaran secara langsung pada PAUD dirasa lebih baik dibanding pembelajaran jarak jauh, karena selain yang telah disebutkan sebelumnya, prinsip-prinsip pembelajaran PAUD akan sulit dicapai melalui pembelajaran jarak jauh.

Pembelajaran tatap muka yang dimaksud disebut dengan pembelajaran tatap muka terbatas. Menurut Sistiarini et al. (2020) pembelajaran tatap muka terbatas adalah pembelajaran tatap muka yang dilakukan dengan menerapkan prokes pencegahan Covid-19 dan memperhatikan persiapan yang dilakukan sekolah sebelum dimulainya pembelajaran tatap muka terbatas, memastikan bahwa pembelajaran tatap muka terbatas berlangsung dengan aman, menentukan secara jelas jumlah hari serta jam pembagia rombongan belajar terbatas dilaksanakan, dan bagaimana sekolah melaksanakan kombinasi antara pembelajaran tatap muka terbatas dengan PJJ (Pembelajaran jarak jauh). Pembahasan ini sangat menarik karena penerapan pembelajaran tatap muka terbatas tidak sama seperti pembelajaran normal sebelumnya. Semua yang terlibat di dalamnya baik orang tua, anak, dan khususnya guru harus menyiapkan strategi-strategi khusus demi berlangsungnya pembelajaran tatap muka terbatas yang nyaman, efektif, serta aman bagi anak. 
Sebaiknya sebelum menerapkan pembelajaran tatap muka terbatas, lembaga PAUD perlu mempersiapkannya sesuai yang dianjurkan pemerintah, supaya pembelajaran tatap muka terbatas dapat berjalan lancar, aman dan nyaman. Hal ini juga diungkapkan oleh Shaleh \& Anhusadar (2021) bahwa mengukur kesiapan lembaga PAUD ketika menyiapkan proses pembelajaran tatap muka sangat penting dilakukan sehingga dapat mengukur kesiapan yang dilakukan lembaga PAUD dalam menyiapkan fasilitas yang sesuai dengan perintah dari pemerintah. Persiapan lembaga PAUD antara lain peserta didik dan guru wajib menggunakan masker, pengecekan suhu tubuh, waktu kegiatan pembelajaran, jarak antar anak didik di dalam kelas, dan kegiatan di luar belajar mengajar harus tetap menjaga protokol kesehatan. kegiatan pembelajaran tatap muka terbatas di PAUD menerapkan beberapa perubahan pembelajaran diantaranya, semua yang terlibat mampu menerapkan prinsip mitigasi dan adaptasi dalam integrasi protokol kesehatan yakni $5 \mathrm{M}$, membuat standar operasional prosedur dalam semua kegiatan, penyekatan ruang kelas, siswa mempunyai alat peraga edukatif dan perlengkapan sanitasi untuk diri sendiri sebagai upaya mengurangi interaksi dan mobilisasi (Sari et al., 2021).

Perubahan-perubahan yang disebutkan di atas tidak berjalan secara keseluruhan. Menurut Yuniatari, yang dikutip Handayani et al. (2021) kegiatan pembelajaran tatap muka terbatas pada PAUD tetap dilakukan dalam tiga tahapan, yaitu kegiatan pembuka, kegiatan inti, istirahat dan penutup. Yang membuat berbeda dengan pembelajaran tatap muka sebelumnya adanya pandemi ialah jumlah kegiatan dalam kegiatan inti. Kegiatan inti yang biasanya dilakukan dengan beberapa aktivitas atau kegiatan, pada pembelajaran tatap muka terbatas hanya dilakukan dengan satu aktivitas pada anak. Adanya perubahan-perubahan tersebut mendorong guru untuk mampu mengembangkan kegiatan dengan keterbatasan waktu, namun meskipun begitu tetap dapat dilakukan dengan adanya Rencana Pelaksanaan Pembelajaran (RPP) yang dibuat oleh guru menyesuaikan dengan kondisi dan situasi sekolah selama masa pandemi covid-19.

Topik pada artikel ini sangat penting dan menarik untuk diketahui dan dibahas karena penerapan pembelajaran tatap muka terbatas tidak seperti penerapan pembelajaran tatap muka normal sebelumnya. Adanya perubahan-perubahan tersebut tentu saja memerlukan persiapan dan adaptasi kebiasaan baru yang dilakukan oleh anak, guru, orang tua, bahkan hingga lembaga sekolah, khususnya lembaga PAUD. Penerapan kebiasaan baru dilakukan supaya pembelajaran tatap muka terbatas pada lembaga PAUD dapat berjalan dengan lancar, aman, nyaman, dan proses pembelajaran tetap efektif. Adapun perbaruan dari penulisan artikel ini ialah memberikan gambaran dan kesimpulan mengenai penerapan pembelajaran tatap muka terbatas pada masa pandemi covid-19 pada PAUD di Indonesia dari penelitianpenelitian sebelumnya. Penelitian ini juga memaparkan hasil penelitian-penelitian sebelumnya terkait pembelajaran tatap muka terbatas di PAUD, sekaligus menyimpulkannya secara singkat sehingga memudahkan para pembaca untuk mendapatkan informasi mengenai pembelajaran tatap muka terbatas di lembaga PAUD.

Topik yang banyak dibahas pada penelitian-penelitian terdahulu mengenai pembelajaran tatap muka terbatas di lembaga PAUD ialah bagaimana seluruh warga sekolah mempersiapkan protokol kesehatan, mengatur jadwal pembelajaran tetap muka terbatas dan belajar dari rumah, kemudian bagaimana menerapkannya pada proses pembelajaran tatap muka di lembaga PAUD. Beberapa hal yang sedikit dibahas pada penelitian-penelitian sebelumnya ialah bagaimana cara guru mengevaluasi pembelajaran tatap muka terbatas di PAUD, mengingat adanya perubahan yang dialami guru dan anak didik selama pembelajaran tatap muka terbatas, seperti pemberian jadwal belajar di rumah dan tatap muka terbatas di sekolah. Hal ini tak kalah pentingnya untuk dibahas karena barkaitan dengan capaian perkembangan anak usia dini di masa pandemi covid-19. 


\section{METODOLOGI}

Penelitian ini merupakan penelitian kualitatif, penelitian kualitatif adalah metode penelitian yang berlandas pada filsafat postpositivisme, digunakan untuk meneliti kondisi obyek yang alamiah, (sebagai lawan penelitian eksperimen) dimana peneliti sebagai instrument kunci, menyajikan datadata dalam bentuk kata-kata atau gambar serta tidak menekankan angka, melakukan analisis data. Metode penelitian kualitatif menggunakan analisis berdasarkan data-data fakta yang ditemukan di lapangan (Sugiyono, 2015).

Teknik pengumpulan data pada penelitian ini menggunakan studi pustaka atau literatur yang melibatkan penemuan, membaca, dan mengevaluasi laporan penelitian dengan baik sebagai laporan pengamatan dan pendapat kasual terkait proyek penelitian yang akan diteliti (Gall et al., 2003). Peneliti mengumpulkan 22 artikel terkait jurnal pembelajaran tatap muka terbatas di PAUD, kemudian disortir sesuai isi pada artikel jurnal menjadi 12 artikel/jurnal yang disesuaikan dengan judul penelitian yang diambil.

Terdapat empat hal yang harus diperhatikan dalam penulisan kajian pustaka menurut Zed, yang dikutip Satrianingrum et al. (2021) antara lain: 1) penelitian kajian pustaka tidak dilakukan eskperimen atau dilihat dari lapangan, penelitian kajian pustaka hanya mengkaji penelitian-penelitian terkait sebelumnya; 2) penelitian yang dilakukan bersifat siap pakai, yakni hanya menggunakan referensi yang tersedia; 3) daftar pustaka yang digunakan lebih banyak menggunakan secondary sources dari pada primary sources; dan 4) referensi yang digunakan tidak terbatas ruang dan waktu.

Penelusuran artikel diambil dari sumber sekunder yaitu buku, jurnal, serta dokumendokumen terkait topik yang mengarahkan penelitian ini untuk memaparkan penerapan pembelajaran tatap muka terbatas di lembaga PAUD. Selain bersumber dari data-data sekunder, penelitian ini juga disusun berdasarkan gagasan penulis sebagai bentuk penarikan kesimpulan. Instrumen yang digunakan dalam penelitian bisa berupa daftar check-list klasifikasi bahan penelitian, skema atau peta penulisan, dan format catatan penelitian (Mirzaqon \& Purwoko, 2017). Berikut ini langkah-langkah penulisan dan analisis studi literatur menurut (Amri et al., 2020): 1) pencarian topik; 2) menentukan judul; dan 3) menyimpulkan. Sedangkan analisis penulisan studi literatur yaitu: 1) pengumpulan data; 2) reduksi data; dan 3) penarikan kesimpulan.

Berdasarkan pemaparan di atas, maka peneliti mencari topik, menentukan judul, melakukan pengumpulan data sekunder (secondary sources) yang didapatkan dari buku, jurnal dan dokumen-dokumen terkait topik yang diambil, kemudian mereduksi data, yakni menajamkan, menggolongkan, menghilangkan yang tidak perlu, dan memberi gagasan individu sebagai bentuk penarikan kesimpulan serta gambaran penerapan pembelajaran tatap muka terbatas di lembaga PAUD. Tahapan analisis penelitian sebagaimana pada gambar 1.

$$
\text { Mengumpulkan data }
$$
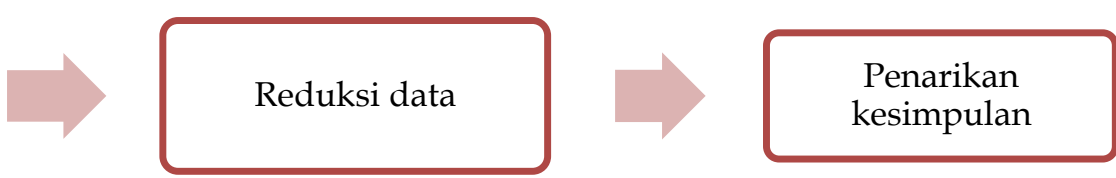

\section{Gambar 1. Tahapan analisis studi literatur}

\section{HASIL DAN PEMBAHASAN}

Hampir 2 tahun sekolah sepi karena tidak ada pembelajaran tatap muka karena pandemi covid-19. Kegiatan pembelajaran digantikan dengan pembelajaran jarak jauh hingga kebijakan pembelajaran tatap muka dari pemerintah muncul. Aturan pemerintah mengenai pembelajaran tatap muka di masa pandemi covid-19 diambil dengan segala pertimbangan karena banyaknya kendala yang dialami oleh siswa maupun guru dalam pelaksanaan pembelajaran online, khususnya PAUD (Husna, 2022). Meskipun kasus positif covid-19 pada anak usia dini terbilang sedikit, namun anak usia dini tergolong pada kelompok yang rentan terpapar virus covid-19 (Prasetiyo, 2020). Oleh karenanya pemerintah mengeluarkan panduan 
pembelajaran tatap muka pada era covid-19, hingga program kebijakan ini disebut dengan pembelajaran tatap muka terbatas (PTMT).

Berdasarkan survey lintas jenjang yang dilakukan oleh Kemendikbud RI, yang dipublish pada halaman web Kementerian Pendidikan dan Kebudayaan (pengelola web kemendikbud, 2021) “per-September 2021, sebanyak 61\% satuan PAUD di Indonesia masih melakukan pembelajaran jarak jauh (PJJ) sedangkan sisanya 39\% satuan PAUD sudah melakukan pembelajaran tatap muka terbatas (PTMT)," Ungkap Dirjen Jumeri. Beliau juga menambahkan bahwasannya seluruh anggota yang terlibat di PAUD harus turut mengawasi transisi belajar dan bermain yang sebelumnya pembelajaran jarak jauh (PJJ) melalui belajar dari rumah, berangsur-angsur diubah menjadi pembelajaran tatap muka terbatas (PTMT) agar berjalan dengan lancar.

Pembelajaran tatap muka terbatas (PTMT) memerlukan beberapa hal yang perlu diperhatikan sebagai bentuk pencegahan penyebaran virus, demi kenyamanan guru maupun siswa yang terlibat didalamnya. Menurut (Lo Moro et al., 2020) hal-hal tersebut antara lain: 1) menggunakan masker, baik anak didik maupun staf dan guru; 2) jaga jarak (fisik), Jarak 1 hingga 2 meter, dan jarak harus lebih dijaga antara staf/guru dengan anak daripada anak dengan anak; 3) mengurangi interaksi, misalnya mengatur jadwal untuk mengurangi kepadatan kedatangan anak; 4) etika pernapasan, memberi intruksi etika pernapasan seperti batuk dan bersin di tisu sekali pakai kemudian langsung membuangnya, ajari anak menghindari perilaku yang melibatkan kontak tangan dan mulut, contohnya memasukkan pena/pensil ke mulut; 5) kebersihan tangan, membiasakan anak untuk mencuci tangan yang kotor menggunakan sabun, dan keringkan dengan tisu sekali pakai atau udara, kebersihan tangan harus dipantau terutama saat kedatangan kesekolah, sebelum makan, setelah menggunakan toilet, dsb; 6) pembersihan ventilasi dan disenfektan harus dibersihkan terutama sebelum masuk sekolah, istirahat, dan akhir pembelajaran, jendela dan pintu terbuka, pembersihan menggunakan disenfektan setidaknya dilakukan sehari sekali pada seluruh bangunan; 7) aktivitas di sekolah, di luar kelas harus lebih disukai ketimbang di dalam kelas; 8) antar jemput anak, dilakukan tidak berhuyung-huyung dan tetap menjaga jarak; dan 9) kantin sekolah, semua yang berada di kantin sekolah harus menggunakan masker, pengelola kantin menawarkan untuk makan di kelas, dan kebersihan kantin dilakukan secara berkala.

Berdasarkan data-data yang telah peneliti kumpulkan dari penelitian-penelitian sebelumnya, peneliti menyortir sesuai dengan isi dan kebutuhan yang dibutuhkan untuk menguraikan informasi tentang penerapan pembelajaran tatap muka terbatas di lembaga PAUD mulai dari persiapan hingga pelaksanaan. Hal-hal yang akan dibahas lebih lanjut antara lain persiapan yang dilakukan lembaga PAUD untuk melaksanakan pembelajaran tatap muka terbatas, dan perubahan-perubahan pada penerapan pembelajaran tatap muka pada umumnya dengan pembelajaran tatap muka terbatas di PAUD. Berikut penjelasan lebih lanjut mengenai beberapa hal yang dibahas sebagai berikut:

\section{Persiapan Pembelajaran Tatap Muka Terbatas}

Rencana dibukanya kembali pembelajaran tatap muka membuat sekolah, khususnya lembaga PAUD harus menyiapkan kepentingan yang diperlukan sesuai anjuran yang diberikan pemerintah. Sehingga persyaratan membuka kembali pembelajaran tatap muka di lembaga PAUD dapat dipenuhi. Selain mempersiapkan kebutuhan yang ada disekolah, persiapan awal yang harus dilakukan lembaga PAUD yakni seorang guru memastikan bahwa peserta didik mendapatkan izin oleh orang tua untuk mengikuti pembelajaran tatap muka dan menandatangani surat pernyataan (Shaleh \& Anhusadar, 2021). Karena orang tua merupakan pihak krusial utama yang berkaitan dengan keputusan untuk mengizinkan anak mengikuti pembelajaran tatap muka. Hal ini sejalan dengan pernyataan (Powa et al., 2021) bahwa persetujuan dari orang tua peserta didik merupakan kunci utama pembelajaran tatap muka di sekolah. 
Surat pernyataan izin orang tua berisi "menerangkan bahwa saya memberikan izin pada anak saya untuk mengikuti pembelajaran tatap muka di sekolah secara bertahap sepanjang masa transisi dengan menerapkan protokol kesehatan sesuai anjuran pemerintah, dan bersedia mengikuti rencana pembelajaran yang sudah diatur oleh pihak sekolah. Demikian surat ini dibuat tanpa paksaan dari pihak manapun untuk digunakan sebagaimana semestinya." (Manik, 2021). Berdasarkan wawancara pada penelitian Shaleh \& Anhusadar (2021) sebagian besar orang tua peserta didik setuju dan mengizinkan anaknya untuk mengikuti pembelajaran tatap muka terbatas sesuai dengan protokol kesehatan yang dianjurkan oleh pemerintah, bahkan para orang tua merasa senang jika pembelajaran tatap muka kembali dibuka, mereka takut apabila anak-anak terus menerus belajar dari rumah akan merasa jenuh karena belajar sendiri, hal itulah yang menyebabkan mereka menandatangani surat izin persetujuan orang tua agar anak-anak mereka kembali belajar tatap muka di sekolah. Hal ini juga senada dengan penelitian Sholikhah (2021) bahwa ketertarikan orang tua terhadap pembelajaran tatap muka dengan protool kesehatan.

Persiapan berikutnya yang harus dilakukan oleh guru dan lembaga PAUD setelah mendapatkan izin dari orang tua anak ialah penerapan protokol kesehatan di sekolah. Menurut Supono \& Tambunan (2021) protokol kesehatan adalah suatu panduan yang berisi aturan-aturan mengenai perilaku hidup bersih dan sehat untuk menjaga kesehatan tubuh supaya terhindar dari penularan penyakit, dalam konteks ini maksudnya ialah penularan covid-19. Memahami bagaimana penyebaran covid-19 kita dapat melindungi diri kita dan orang lain adalah langkah pertama yang penting menetapkan prosedur dan protokol di kelas (UNICEF, 2020). Menurut Shaleh \& Anhusadar (2021) protokol kesehatan di sekolah merupakan segenap aturan sebagai upaya pencegahan meluasnya penyebaran covid-19 yang diakibatkan virus corona di institusi pendidikan. Oleh karena itu Protokol kesehatan sesuai anjuran pemerintah pada sarana prasarana sangat penting untuk dipersiapkan sebelum melaksanakan pembelajaran tatap muka (Pattanang et al., 2021).

Standar operasional prosedur (SOP) protokol kesehatan untuk menunjang kegiatan pembelajaran di sekolah ialah $5 \mathrm{M}$, yakni menggunakan masker, menjaga jarak, mencuci tangan, menghindari kerumunan, dan mengurangi mobilitas) (Sari et al., 2021). Sama halnya dengan pendapat sebelumnya, menurut Sholikhah, 021) wilayah yang memungkinkan melakukan pembelajaran tatap muka terbatas dengan catatan menerapan protokol kesehatan di lingkungan sekolah antara lain menggunakan masker, menggunakan handsanitizer, cuci tangan menggunakan sabun dengan air yang mengalir, dan menjaga jarak demi menjaga keselamatan bersama. Disebutkan oleh Husna (2022) hal yang perlu diperketat dalam penerapan protokol kesehatan penggunaan masker dan menjaga jarak. Berdasarkan aturan yang disebutkan oleh (Kemendikbud \& Kementerian Agama, 2021), dalam panduan penyelenggaraan pembelajaran pauddikdasmen di masa pandemi covid-19, kesiapan pembelajaran tatap muka terbatas pada TK, BA, KB, TPA antara lain: 1) ketersediaan sarana sanitasi dan kebersihan, paling sedikit memiliki toilet yang bersih dan layak; 2) sarana cuci tangan pakai sabun (CTPS) dengan air mengalir ataupun cairan pembersih tangan (hand sanitizer), disinfektan; 2) dapat mengakses fasilitas layanan kesehatan, seperti puskesmas, klinik, rumah sakit, dsb.; 3) kesiapan menerapkan wajib masker atau ruang tembus pandang bagi anak disabilitas rungu; 4) memiliki thermogun (pengukur suhu tembak); 5) mendata warga yang tidak dapat melakukan kegiatan, seperti memiliki kondisi komorbid yang tidak terkontrol, tidak memiliki transportasi sehingga memungkinkan penerapan jaga jarak; 6) memiliki data warga sekolah yang memiliki riwayat bepergian jauh ke tempat berwilayah tingkat risiko penyebaran covid-19 tinggi, dan memiliki data warga sekolah yang memiliki riwayat kontak dengan orang yang terkonfirmasi positif covid-19. Tak hanya sampai disitu, menurut Hardiyanti et al. (2021) persiapan pembelajaran tatap muka terbatas di PAUD juga harus didukung kompetensi guru dalam menyiapkan pembelajaran aktif, kreatif, dan menyenangkan secara terus menerus untuk membekali guru dalam penyelenggaraannya. 
Persiapan lainnya yang harus dilakukan oleh guru dan lembaga PAUD ialah mengubah beberapa struktur penataan ruang kelas untuk adaptasi kebiasaan baru yang tentu juga mengubah fungsinya (Sari et al., 2021). Lebih rinci dijelaskan oleh (Novitasari, 2021) sarana protokol kesehatan di PAUD antara lain: 1) sarana CTPS (cuci tangan pakai sabun) yaitu tersedia kecukupan (sarana CTPS, sabun cuci tangan, tersedianya air bersih disetiap CTPS, dan Tersedianya handsanitizer; 2) Masker/face shield, lembaga PAUD memberi masker/face shield pada tiap anak dengan jumlah yang mencukupi; 3) Vitamin untuk kekebalan daya tahan tubuh; 4) perlengkapan disinfeksi, yaitu penyemprotan seluruh area sekolah dengan disenfektan yang dilakukan setiap pergantian sift; 5) sarana kebersihan tersedia dan cukup; 6) Thermo gun (pengukur suhu tembak), jumlahnya mencukupi dan mampu bekerja dengan baik.

\section{Pelaksanaan Pembelajaran Tatap Muka Terbatas di PAUD}

Persiapan yang telah dilakukan oleh guru dan lembaga PAUD dalam menyongsong pembelajaran tatap muka terbatas, dapat langsung melaksanakannya dengan terus mematuhi persyaratan-persyaratan pembelajaran tatap muka terbatas yang diberi oleh pemerintah. Beberapa pelaksanaan pembelajaran tatap muka yang telah dilakukan di lembaga PAUD salah satunya pada penelitian Supriyanto et al. (2021) di PAUD Tunas Bangsa, bahwa selama pembelajaran tatap muka terbatas, anak-anak mampu menerapkan protokol kesehatan, bahkan anak mampu mempraktikkan menggunakan masker, mengukur suhu, mencuci tangan, memakai tisu dan hand sanitizer secara mandiri dan urutan yang benar. Lebih detail dari pendapat sebelumnya, mengenai jadwal pembelajaran tatap muka terbatas PAUD yang dijelaskan oleh Handayani et al. (2021) pada PAUD As-Shofa Tembilahan Hulu, dilakukan 3 kali seminggu pembelajaran tatap muka di sekolah, 2 kali seminggu dilakukan dirumah guru, dan satu kali seminggu dilakukan di mushola PAUD As-Shofa Tembilahan Hulu. Sistem pembelajaran tatap muka terbatas pada PAUD As-Shofa Tembilahan Hulu sama seperti saat sebelum pandemi, yakni meliputi kegiatan pembuka, inti, istirahat makan, dan penutup. Yang menjadikannya berbeda ialah jumlah kegiatannya, apabila kegiatan pembelajaran sebelum pandemi dilakukan dengan 4 kegiatan, maka saat pembelajaran tatap muka terbatas hanya dilakukan dengan 1 kegiatan. Perubahan selanjutnya terdapat pada model pembelajaran di PAUD As-Shofa Tembilahan Hulu, sebelum pandemi, model pembelajaran menggunakan model pengaman sudut, namun dimasa pandemi model ini tidak dilaksanakan karena anak hanya mengerjakan 1 kegiatan, dan model pembelajaran yang dilakukan adalah klasikal.

Hampir sama dengan pelaksanaan pembelajaran tatap muka terbatas sebelumnya, dijelaskan oleh Muazimah \& Diana (2021) pada TK Mutiara Ibu Kampar Kiri Hilir, melakukan pembelajaran tatap muka terbatas dengan kegiatan pembuka, kegiatan inti, dan kegiatan penutup. Yang membuatnya berbeda, pembelajaran ini belum dilakukan di sekolah, melainkan di rumah guru kelas dengan waktu yang relatif singkat, tidak ada waktu istirahat/makan, dan hanya melakukan satu kegiatan saja. Pembelajaran tatap muka terbatas ini menggunakan model pembelajaran klasikal, dan pelaksanaannya dilakukan seperti jam sekolah, yaitu dari senin hingga sabtu. Siswa TK Mutiara Ibu Kampar Kiri Hilir berjumlah 22 orang dalam satu kelas, namun guru membaginya kelompok belajarnya menjadi 3 kelompok, yang terdiri dari 7 hingga 8 orang setiap kelompok. Setiap kelompok dapat melakukan pembelajaran tatap muka terbatas satu kali dalam seminggu. Menurut Shaleh \& Anhusadar (2021) Penerapan pembelajaran tatap muka terbatas di PAUD harus memperhatikan jarak antar anak, selain itu fasilitas yang digunakan harus sesuai dengan protokol kesehatan, seperti pengaturan tempat duduk yang telah dianjurkan, fasilitas cuci tangan dan menjaga kebersihan seluruh peralatan yang digunakan anak. Tak lupa melakukan physical distancing dengan cara membatasi anak maksimal 10 orang per-rombel, mengatur ruang kelas, membuat jarak minimal 6 kaki setiap pusat kegiatan anak, mengingatkan anak untuk tidak berbagi makanan, minuman, dan peralatan main dengan teman. 
Tantangan terberat dalam pembelajaran tatap muka terbatas adalah pelaksanaannya. Berdasarkan penelitian yang dilakukan Husna (2022) di TK AF, TK AG, TK AB dan TK WH cenderung sama, yakni anak datang menggunakan masker, diantar dengan jaga jarak yang ditentukan sekolah, guru berjaga di beberapa titik sebagai upaya memastikan anak-anak mematuhi protokol kesehatan dan SOP di sekolah, anak datang tanpa berjabat tangan dengan guru, selanjutnya anak berbaris untuk dicek suhu tubuh, kemudian anak-anak mencuci tangan dengan air mengalir, mengeringkannya, barulah anak-anak dipersilahkan masuk ke kelasnya masing-masing. Adapun pelaksanaan pembelajaran tatap muka terbatas di TK AF, TK AG, TK AB dan TK WH dapat berjalan dengan baik, anak-anak mampu mengikuti dan arahan dari guru, dan mampu mandiri mengikuti kebiasaan baru di sekolah. Sama halnya dengan penerapan sebelumnya, menurut Ochavillo, yang dikutip Harahap \& Purwanta (2021) pembelajaran tatap muka di PAUD pada masa pandemi dilakukan dengan menggunakan shift, memperhatikan protokol kesehatan, dan sebaiknya menerapkan rasio 1 banding 15, untuk instrastruktur-murid, dan 1 banding 1 untuk perlengkapan anak.

Pembagian jadwal/waktu pembelajaran tatap muka terbatas pada PAUD di masa pandemi dibagi menjadi 2 shift pembelajaran, yakni pagi dan siang. TK Ade Lina menggunakan metode shift yang dilakukan dengan bergantian hari dengan kelas lainnya, kelas A melakukan pembelajaran di pagi hari, dan kelas B di siang hari. Hal ini menimbulkan kebingungan pada orang tua saat pelaksanaannya sehingga menimbulkan keramaian. problematika lainnya yang ditemui pada pembelajaran tatap muka PAUD di masa pandemi adalah penerapan social distancing, hal ini sulit terapkan karena fasilitas ruangan yang minim (Harahap \& Purwanta, 2021), dan anak usia dini merupakan makhluk sosial yang tinggi, Aisyah dan Siti yang dikutip (Harahap \& Purwanta, 2021). Oleh karenanya menimbulkan kekhawatiran disiplin dalam penerapan protokol kesehatan (Harahap \& Purwanta, 2021).

Serupa dengan pelaksanaan tatap muka terbatas di TK sebelumnya, TK Negeri Pembina Kalinegara (Yoga, 2021) melaksanakan pembelajaran tatap muka terbatas dengan menerapkan protokol kesehatan, seperti tidak melepas masker, menyemprot tempat belajar mengajar dengan disinfektan setiap sebelum dan setelah kegiatan, menyiapkan tempat sampah yang diberi plastic supaya tidak terkontaminasi saat membuang sampah, selain itu ruang kelas tidak menggunakan taplak meja, tidak menggunakan gorden di ruang kelas, jarak meja dan kursi anak 1,5 meter. Adapun TK Negeri Pembina Kalinegara menyiapkan 5 ruang kelas untuk pembelajaran tatap muka ini, yang diisi oleh 5 orang anak pada setiap kelasnya. Hal serupa juga dilakukan pada TK Aisyiyah Bustanul Athfal 5 Bungah, yang ditulis oleh Mufrika (2021) pembelajaran tatap muka terbatas di TK tersebut dilakukan dengan prosedur 5 anak dalam satu kelas. Untuk lebih mengenal pada kebiasaan baru, guru menjelaskan protokol kesehatan yang ada di sekolah, melalui cuci tangan saat datang dan pulang sekolah, mengingatkan anak untuk tidak bermain dulu, dan yang diperbolehkan hanya makannan ringan atau bekal dari rumah.

Hal berbeda ditemukan pada TKK Kanan Jakarta, yang diteliti oleh (Meriana \& Tambunan, 2021), penyelenggaraan kegiatan tatap muka, sekolah telah mempersiapkan sarana prasarana sesuai dengan standar protokol kesehatan, pendidik dan tenaga pendidik telah melakukan vaksinasi sejak bulan Maret 2021, dan mengutamakan pertumbuhan dan perkembangan anak. adapun pelaksanaannya sebagai berikut: 1) hybrid learning, yakni perpaduan tatap muka dan sebagian dalam jaringan secara bersamaan. Hal ini dilakukan karena memperhatikan kapasitas yang diizinkan; 2) Penyusunan kurikulum khsusus pembelajaran tatap muka terbatas disusun mulai dari kerangka pembelajaran, proses pembelajaran, hingga evaluasi tatap muka terbatas berlansung; 3) memaksimalkan berbagai aplikasi pendukung pembelajaran, platform yang dikuasai guru, dan memaksimalkan penggunaan learning management system yang digunakan untuk penyampaian pembelajaran; dan 4) memastikan pembelajaran tatap muka terbatas dilakukan dengan menguatkan karakter, mengembalikan motivasi dan semangat belajar anak. 
Hampir sama dengan hasil penelitian-penelitian sebelumnya, penelitian yang dilakukan Ni'mah et al. (2020) di TK Dharma Wanita Karangsari, tatap muka dilaksanakan dengan waktu pelaksanaan 1 jam 30 menit, terdiri dari pembukaan 15 menit, kegiatan inti 60 menit, dan penutup 15 menit. Pembelajaran mulai dilakukan pada pukul 08.00 dan berakhir pada 09.30 pagi. Hari aktif luring 3 kali dalam seminggu dengan tetap menerapkan protokol kesehatan. Guru dan anak wajib menggunakan masker, mencuci tangan sebelum dan sesudah kegiatan, menyediakan hand sanitizer dan luas kelas $12 \mathrm{~m}^{2}$, setiap anak mendapatkan ruang main $1,7 \mathrm{~m}^{2}$.

Berdasarkan penjabaran informasi yang didapatkan dari penelitian-penelitian di atas, penerapan pembelajaran tatap muka terbatas khususnya pada lembaga PAUD, sudah sepatutnya dipersiapkan sebaik mungkin. Hal ini dilakukan supaya dalam proses pembelajaran dapat dilaksanakan dengan aman, nyaman, dan tetap efektif. Persiapan yang dilakukan guru dan lembaga PAUD juga harus disesuaikan dengan aturan pemerintah yang telah diberlakukan. Adapun pelaksanaan pembelajaran tatap muka di lembaga PAUD dilakukan dengan beragam cara, namun harus tetap mematuhi batasan-batasan dalam penerapannya.

\section{SIMPULAN}

Penelitian ini membahas pembelajaran tatap muka terbatas di lembaga PAUD dengan beragam ketentuan yang dianjurkan oleh pemerintah. Guru maupun lembaga PAUD harus menyiapkan syarat-syarat tersebut yakni: menyiapkan protokol kesehatan, seperti penyediaan masker, sarana CTPS, hand sanitizer, thermo gun, disinfektan, dapat mengakses layanan kesehatan, dan menyiapkan surat persetujuan orang tua. Penerapan pembelajaran tatap muka terbatas di PAUD harus mematuhi prinsip protokol kesehatan $5 \mathrm{M}$ melalui upaya dengan cara memberi shift belajar, memberi jadwal tatap muka, membagi anak menjadi beberapa kelompok belajar, memberi jarak 1,5 meter setiap anak, kegiatan dilakukan dengan kegiatan pembuka, inti, dan penutup, namun kegiatan hanya dengan 1 kegiatan.

\section{UCAPAN TERIMA KASIH}

Alhamdulillah puji syukur kepada Allah penulis panjatkan, karena atas rahmat dan hidayah-Nya lah penulis dapat menyelesaikan penulisan artikel ini. Tidak lupa ucapan terima kasih pada orang tua atas doa dan dukungannya, dosen pembimbing yang memberi arahan, dan masukan, serta teman-teman yang telah membantu memberi masukan dalam penulisan artikel ini. Semoga artikel ini dapat memberikan pengetahuan dan informasi baru tentang penerapan pembelajaran tatap muka terbatas di PAUD

\section{DAFTAR PUSTAKA}

Amri, M. I. U., Bahtiar, R. S., \& Pratiwi, D. E. (2020). Dampak penggunaan gadget terhadap kemampuan interaksi anak sekolah dasar pada situasi pandemi covid-19'. Trapsila: Jurnal Pendidikan Dasar, 2(02), 14. https:// doi.org/10.30742/tpd.v2i2.933

Gall, M. D., Gall, J. P., \& Borg, W. R. (2003). Educational Research An Introduction (Seventh Edition) (7th ed.). Allyn and Bacon.

Handayani, F. F., Hibana, \& Surahman, S. (2021). Implementasi pembelajaran daring dan luring bagi anak usia dini pada masa pandemi covid-19. Mitra Ash-Shibya: Jurnal Pendidikan Dan Konseling, 4(02), 103-116. https://doi.org/10.46963/mash.v4i02.358

Harahap, S. A., \& Purwanta, E. (2021). Problematika Pembelajaran Daring dan Luring Anak Usia Dini bagi Guru dan Orang tua di Masa Pandemi. Jurnal Obsesi: Jurnal Pendidikan Anak Usia Dini, 5(2), 1825-1836. https://doi.org/10.31004/obsesi.v5i2.1013

Hardiyanti, W. E., Sulkifly, \& Mori, J. T. S. (2021). Kesiapan Penerapan Pembelajaran Aktif , Kreatif dan Menyenangkan Bagi Anak Usia Dini di Era New Normal Proses perkembangan dan pembelajaran anak usia dini tengah menghadapi kendala 
diakibatkan dunia dan Indonesia khususnya sedang dilanda wabah pandemik ya. Student Journal of Early Childhood Education, 1(1), 1-10.

Husna, M. (2022). Eksplorasi Penerapan Pembelajaran Tatap Muka Terbatas pada Jenjang PAUD di Masa Kebiasaan Baru. Jurnal Obsesi: Jurnal Pendidikan Anak Usia Dini, 6(3), 1846-1858. https:// doi.org/10.31004/obsesi.v6i3.1814

Isdijoso, W., Suryahadi, A., Suryadarma, D., Sumarto, S., Usman, S., Yumna, A., Diningrat, R. A., Rahman, M. A., Izzati, R. Al, Bima, L., Bachtiar, P. P., Kurniawan, A., Wahyu, Y. F. M., Hastuti, Saputri, N. S., Fillali, R., Kusuma, A. Z. D., Arfyanto, H., Fatah, A. R. (2020). Studi dampak sosial-ekonomi pandemi covid-19 di Indonesia. SMERU Research Institute. https://smeru.or.id/id/content/studi-dampak-sosial-ekonomi-pandemicovid-19-di-indonesia

Kemendikbud, \& Kementerian Agama. (2021). Panduan penyelenggaraan pembelajaran pauddikdasmen di masa pandemi covid-19.

Lo Moro, G., Sinigaglia, T., Bert, F., Savatteri, A., Gualano, M. R., \& Siliquini, R. (2020). Reopening schools during the COVID-19 pandemic: Overview and rapid systematic review of guidelines and recommendations on preventive measures and the management of cases. International Journal of Environmental Research and Public Health, 17(23), 1-21. https:// doi.org/10.3390/ijerph17238839

Manik, M. (2021). Kesiapan penerapan pembelajaran tatap muka (PTM) di masa new normal pandemi covid-19 (studi kasus di SMPN 2 Siberut Utara, Kabupaten Kepulauan Mentawai). Jurnal Edusciense, 8(1), 20-29. https://doi.org/10.36987/jes.v8i1.2115

Meriana, T., \& Tambunan, W. (2021). Evaluasi Persiapan Sekolah Tatap Muka Di Tkk Kanaan Jakarta. Jurnal Manajemen Pendidikan, 10(1), 1-12. https://doi.org/10.33541/jmp.v10i1.3260

Muazimah, A., \& Diana, R. R. (2021). Strategi pembelajaran pada masa pandemi Covid-19 di TK Permata Ibu Kampar Kiri Hilir. JP PAUD FKIP Untirta, 8(November), 127-134. https://doi.org/10.30870/jpppaud.v8i2.11842

Mufrika. (2021). Bahagia di PTM Terbatas TK Aisyiyah Bungah. Pwmu.Com. https:// pwmu.co/209284/09/16/bahagia-di-ptm-terbatas-tk-aisyiyah-bungah/

Ni'mah, N. K., Rakhmawati, D., \& Septiana, L. (2020). Upaya meningkatkan perkembangan bahasa dengan menggunakan media video pembelajaran pada anak usia 5-6 tahun di TK Dharma Wanita Karangsari. Jurnal Dimensi Pendidikan, 16(2), 14-28. https://doi.org/10.26877/dm.v16i2.7332

Novitasari, N. (2021). Penerapan Protokol Kesehatan Dalam Pembelajaran Tatap Muka Pada Masa Era New Normal Di Paud Plus Darussalam Bojonegoro. Al-Hikmah : Indonesian Journal of Early Childhood Islamic Education, 5(1), 39-50. https://doi.org/10.35896/ijecie.v5i1.191

Pattanang, E., Limbong, M., \& Tambunan, W. (2021). Perencanaan Pelaksanaan Pembelajaran Tatap Muka Di Masa Pandemi Pada Smk Kristen Tagari. Jurnal Manajemen Pendidikan, 10(2), 112-120. https://doi.org/10.33541/jmp.v10i2.3275

pengelola web kemendikbud. (2021). PTM Terbatas Cara Terbaik Percepat Pemulihan PAUD Berkualitas. Kementerian Pendidikan Dan Kebudayaan.

Powa, N. W., Tambunan, W., \& Limbong, M. (2021). Analisis Persetujuan Orang Tua Terhadap Rencana Pembelajaran Tatap Muka Terbatas Di Smk Santa Maria Jakarta. Jurnal Manajemen Pendidikan, 10(2), 100-111. https:// doi.org/10.33541/jmp.v10i2.3274

Prasetiyo, A. (2020). Media Internet Sebagai Sarana Edukasi Pada Anak Usia Dini Tentang Covid-19. Journal of Informatics and Vocational Education, 3(2), 43-46. https://doi.org/10.20961/joive.v3i2.43056

Sari, D. yunia, Rahma, A., \& Rahaju, I. (2021). Penataan Ulang Infrastruktur PAUD dalam Rencana Pembukaan Kembali Sekolah di Masa Pandemi Covid-. Jurnal Obsesi : Jurnal Pendidikan Anak Usia Dini, 6(3), 1615-1627. 
Satriana, M., Buhari, M. R., Makmun, M., Maghfirah, F., Haryani, W., Wahyuningsih, T., Wardana, H., Sagita, A. D. N., Oktamarina, L., \& Bakar, A. A. (2021). Persepsi Guru PAUD terhadap Pembelajaran Online: Fenomena Masa Pandemi Covid-19. Jurnal Obsesi : Jurnal Pendidikan Anak Usia Dini, 6(1), 362-373. https:// doi.org/10.31004/obsesi.v6i1.1353

Satrianingrum, A. P., Setiawati, F. A., \& Fauziah, P. Y. (2021). Pembelajaran Jarak Jauh pada PAUD: Studi Literatur berbagai Metode Pembelajaran pada Masa Pandemi di berbagai $\begin{array}{llll}\text { Tempat. Jurnal } & \text { Pendidikan }\end{array}$ https://journal.uny.ac.id/index.php/jpa/article/view/37320

SE Nomor 4 tahun 2020 tentang pelaksanaan kebijakan pendidikan dalam masa darurat penyebaran corona virus disease (covid-19), $300 \quad$ (2020). https:// doi.org/10.33474/yur.v4i2.11239

Shaleh, M., \& Anhusadar, L. (2021). Kesiapan Lembaga PAUD dalam Pembelajaran Tatap Muka pada New Normal. Jurnal Obsesi : Jurnal Pendidikan Anak Usia Dini, 5(2), 21582167. https:// doi.org/10.31004/obsesi.v5i2.1139

Sholikhah, I. (2021). Analisis Kesiapan Orang Tua Menghadapi Pembelajaran Tatap Muka ( PTM ) di Masa Pandemi. Jurnal Inovasi Dan Riset Akademik, 2(7), 925-940. https:// doi.org/10.47387/jira.v2i7.181

Supono, T., \& Tambunan, W. (2021). Kesiapan penerapan protokol kesehatan di lingkungan sekolah dasar pangudi luhur jakarta selatan 1. Jurnal Manajemen Pendidikan, 10(02), 57-65. https://doi.org/10.33541/jmp.v10i2.3269

Supriyanto, A., Rozaq, J. A., Santosa, A. B., \& Listiyono, H. (2021). Uji Coba Persiapan Pembelajaran Tatap Muka Masa Normal Baru PAUD " Tunas Bangsa " Semarang. $\begin{array}{llll}\text { Jurnal Pengabdian } \quad \text { Pada } & \text { 753-763), }\end{array}$ https:/ / doi.org/10.30653/002.202163.834 Uji

Syah, R. H. (2020). Dampak Covid-19 pada Pendidikan di Indonesia: Sekolah, Keterampilan, dan Proses Pembelajaran. SALAM: Jurnal Sosial Dan Budaya Syar-I, 7(5). https:// doi.org/10.15408/sjsbs.v7i5.15314

UNICEF. (2020). Classroom precautions during COVID-19 Tips for teachers to protect themselves and their students. Unicef. https://www.unicef.org/coronavirus/teachertips-classroom-precautions-covid-19

Yoga, C. (2021). TK Pembina Kalinegoro Mulai Pembelajaran Tatap Muka Terbatas. Berita Magelang. http:// beritamagelang.id/tk-pembina-kalinegoro-mulai-pembelajarantatap-muka-terbatas 